\title{
Chronic Active EBV Infection of T-and NK- Cell Type, Systemic Form
}

National Cancer Institute

\section{Source}

National Cancer Institute. Chronic Active EBV Infection of T-and NK-Cell Type, Systemic

Form. NCl Thesaurus. Code C126348.

An on-going Epstein-Barr virus (EBV) infection characterized by repeated infectious

mononucleosis-like symptoms, a very high titer of anti-EBV antibodies, and high levels of Epstein-Barr virus nucleic acids. Patients with CAEBV often develop progressive cellular and humoral immunodeficiency with pancytopenia and hypog ammag lobulinemia. 